\title{
Investigation of Seasonal and Cooking Effects on the Bioaccessibility of Elements in Most Consumed Fish in Turkey
}

\author{
Ayla Güngör ${ }^{1}$, Derya Kara ${ }^{1, *}$ (D) \\ ${ }^{1}$ Balıkesir University, Department of Chemistry, Art and Science Faculty, 10100 Balıkesir, Turkey.
}

\section{Article History \\ Received 02 May 2019 \\ Accepted 10 September 2019 \\ First Online 17 September 2019 \\ Corresponding Author \\ Tel.: +902666121000 \\ E-mail: dkara@balikesir.edu.tr}

\author{
Keywords \\ Food analysis \\ Fish \\ Trace elements \\ Bioaccessibility \\ Chemometric analysis
}

\begin{abstract}
An in-vitro gastrointestinal extraction method has been performed to determine the bioaccessibility of $\mathrm{As}, \mathrm{Co}, \mathrm{Cu}, \mathrm{Fe}, \mathrm{Mn}, \mathrm{Ni}$, Se and $\mathrm{Ti}$ in the most consumed fish (anchovy, bream, sardines, horse mackerel, seabass and whiting) in Turkey. The effects of the season, i.e. September and March and the effects of cooking on the bioaccessibility of these elements were analysed statistically. Classification of the fish samples was performed using ANOVA and Principal Component Analysis chemometric methods to determine whether the bioaccessiblity of these elements is higher in the gastric or intestinal digestions. In general, the results showed that trace elements are more bioaccessible in raw fish compared with cooked and in September irrespective of whether the fish is fattier or not. In addition, the bioaccesible concentrations of these elements in anchovy, sardines and horse mackerel were higher than in the other species. It shows that these fish types have higher levels of elemental accumulation than seabass, bream and whiting.
\end{abstract}

\section{Introduction}

Fish is a highly nutritional healthy food rich in omega-3 fatty acids. These help to maintain functioning of the human body properly but also supply big health benefits. They also contain essential amino acids, proteins, trace elements and vitamins especially vitamin D (Sioen, Henauw, Verdonck, Thuyne \& Camp. 2007). Several research studies have shown that eating fish regularly decreases the risk of heart disease, autoimmune diseases including type 1 diabetes, hypertension, Alzheimer's disease, strokes and cancer etc. (Simopoulos. 1997; Sioen et al. 2007). Fish are also known to build up substantial amounts of toxic metals in their cells and these are potentially harmful to humans. Therefore, suitable measures should be taken to monitor the chemicals in fish deriving from its consumption.
Several cooking methods such as grilling, frying, boiling or baking are used to prepare and cook fish for the diet. But some fish types for example tuna, salmon, seabass, mackerel etc. are also eaten raw and are used to prepare sushi or sashimi. These preparation and cooking processes may differentiate the amount and the species of chemical components in fish (Burger, Dixon, Boring \& Gochfeld. 2003; Ersoy \& Zeren. 2009, Ersoy, Yanar, Küçük Gülmez \& Çelik. 2006; Gokoglu, Yerlikaya \& Cengiz. 2004; He, Ke \& Wang. 2010; Perello, Martí-Cid, Llobet \& Domingo. 2008).

Determination of the total concentration of a metal ion does not always indicate the amount that is available to the body. Bioaccessibility refers to the proportion of a drug or other substance absorbed by the body' circulatory system that represents the amount of such substance passing from the food into the digestive tract under simulated conditions. These are more important 
when estimating the possible health effects of a drug or a component in food. Only a proportion of the bioaccessible quantity of the substance will be absorbed (Garrett, Failla \& Sarama. 1999; Oomen, Rompelberg, Bruil, Dobbe, Pereboom \& Sips. 2003; Versantvoort, Oomen, Van de Kamp, Rompelberg \& Sips. 2005). The ingested toxic elements in a foodstuff that passes through the gut wall into the systemic circulation system could potentially have an adverse effect (Wang,et al.,2013; Lorenzi, Entwistle, Cave, Wragg \& Dean. 2012). The bioavailability of components in food can be significantly different when type of food and the processing methods such as boiling, frying, etc. are changed (Wienk, Marx \& Beynen. 1999; Van het Hof, West, Weststrate \& Hautvast. 2000). Many harmful substances in food can be available to human body by ingestion. Health risk assessments in humans should therefore be performed to reveal the toxic risks of these contaminants. Only in vivo studies should be carried out to determine bioavailability of compounds in food. Due to physiological differences between humans and experimental animals, the bioavailability cannot be obtained correctly. Therefore, bioaccessible amounts of foods to the body can be determined by using different in-vitro gastrointestinal extraction methods (Crews, Burrell \& McWeeny. 1983; Kafaoglu, Fisher, Hill \& Kara. 2016; Miller, Schricker, Rasmussen \& Van Campen. 1981; Ruby et al. 1993; Hack \& Selenka. 1996). Biaccessibility data are obtained using processes that mimic the extraction of the food in the human digestive juices secreted by the stomach and the small intestine (Cave et al. 2002; Intawongse \& Dean. 2006; Intawongse \& Dean. 2008; Meunier et al. 2010; Palumbo-Roe et. al. 2005; Wragg et. al. 2007).

The effects of season on the total concentration of the elements in fish have been investigated. The highest total concentrations of elements in fish are observed at the end of winter and at the beginning of spring and the lowest concentrations at the end of summer (Philips 1980). A similar seasonal pattern of the accumulation of the elements in fish was observed by several other researchers (Güngör \& Kara. 2018; Zayed et al. 1994; Joyeux et al. 2004). It can be concluded that bioaccumulation of elements in fish varies depending on the season. Therefore, it could increase the exposure of the public to the elements by consuming them in their diet (Chakraborty et al. 2003).

In this work, the physiologically-based extraction test (PBET) that involves using model stomach and intestinal media comprising inorganic, organic and biochemical components at body temperature and under laboratory conditions is used. The bioaccessible amounts of As, Co, $\mathrm{Cu}, \mathrm{Fe}, \mathrm{Mn}, \mathrm{Ni}$, Se and Ti in gastric and intestinal fractions of raw and cooked fish from the Saroz Bay area of the Marmara Sea were determined in both September and March. The fish species investigated were: bream (Sparus aurata), anchovy (Engraulis encrasicolus), horse mackerel (Trachurus trachurus), seabass (Dicentrarchus labrax), sardine (Sardina pilchardus) and whiting
(Gadiculus argenteus).These fish species were chosen because they are amongst the most commonly consumed fish in Turkey. Principal component analyses and correlation analyses were used to understand if any significant differences for the bioaccessibility of the analytes between cooked and uncooked fish in each season exist. Also the evaluation of the bioaccesibility with regards to season, i.e. when the fish species have different fat content was investigated.

\section{Materials and Methods}

\section{Reagents and Solutions}

A reverse osmosis system was used to obtain purified water. A multi-element stock supplied by Quality Control Standard QC-26 (CPI International, The Netherlands). Bile salts was supplied by Fluka (SigmaAldrich, St. Louis, MO, USA). Acetic acid was supplied by Riedel de Haen (Riedel-de Haen AG, Buchs SG, Switzerland). Hydrochloric acid and lactic acid were supplied by Merck (Merck, Darmstadt, Germany). Nitric acid, sodium malate, sodium bicarbonate, pepsin, sodium citrate and pancreatin were supplied by SigmaAldrich (Sigma-Aldrich, St. Louis, MO, USA).

\section{Instrumentation}

An $X$ Series 2, Inductively coupled plasma mass spectrometry (ICP-MS) instrument (Thermo Scientific, Hemel Hempstead, UK) was used to determine ${ }^{75} \mathrm{As}$, ${ }^{59} \mathrm{Co},{ }^{65} \mathrm{Cu},{ }^{56} \mathrm{Fe},{ }^{55} \mathrm{Mn},{ }^{60} \mathrm{Ni},{ }^{77} \mathrm{Se}$ and ${ }^{47} \mathrm{Ti}$ in the extracts of gastric and intestinal ingestions of the fish samples and in the standards. The ICP-MS instrument was operated under the conditions given in our previous work (Güngör \& Kara. 2018).

\section{Sample Preparation}

The preparation of anchovy, bream, horse mackerel, sardine, seabass and whiting for the gastric and intestinal analyses were given in detail in our previous work (Güngör \& Kara. 2018).

\section{Modified PBET Method}

A modified procedure similar to that used by Kafaoğlu et. al. 2016 was adopted using an accurately weighed aliquot (approximately $12.5 \mathrm{~g}$ ) of the raw or of the cooked fish.

\section{Sample Analysis}

The concentrations of ${ }^{75} \mathrm{As},{ }^{59} \mathrm{Co},{ }^{65} \mathrm{Cu},{ }^{56} \mathrm{Fe},{ }^{55} \mathrm{Mn},{ }^{60} \mathrm{Ni}$, ${ }^{77} \mathrm{Se}$ and ${ }^{47} \mathrm{Ti}$ were determined using ICP-MS. To obtain reliable results, indium and iridium mixture was added to the gastric phase samples and their blanks as well as the calibration standards to give a final concentration of the internal standard of $100 \mu \mathrm{g} \mathrm{L}^{-1}$. Since these internal 
standards require acidic conditions, a Cesium solution to give a final concentration of $100 \mu \mathrm{g} \mathrm{L}^{-1}$ was added to the intestinal phase samples and their blanks and calibration standards. All results are given as the mean of the three replicate sample preparations. The statistical calculations were performed using the SPSS 16 statistics Programme.

\section{Results}

\section{The Cooking Effect}

The in-vitro gastrointestinal extraction method was applied to cooked and raw fish caught in September and March. A one-way ANOVA test was applied to the results to test whether there is a significant difference between the concentrations of the analytes present in gastric and intestinal phase extracts from raw and cooked fish in both September and March.

A significant difference in the concentrations of $\mathrm{Co}, \mathrm{Ni}$ and $\mathrm{Se}$ in September and $\mathrm{As}, \mathrm{Co}, \mathrm{Ni}$, Se and $\mathrm{Ti}$ in March was observed for raw and cooked bream in the gastric phase. From the concentrations of these elements shown in Table 1, the bioaccessible concentrations of $\mathrm{Ni}$ are lower in raw bream than in cooked bream while Se and Co concentrations are lower when the bream is cooked in September. The concentrations of As, Co, Ni, Se and Ti for March in the gastric phase are lower for the cooked bream than the raw bream. The statistical $P$ values of $\mathrm{As}, \mathrm{Cu}, \mathrm{Mn}$ and $\mathrm{Ni}$, in September and for $\mathrm{As}, \mathrm{Cu}$, $\mathrm{Fe}, \mathrm{Ni}$ and $\mathrm{Se}$ in March calculated using a one-way ANOVA test were lower than 0.05 for raw and cooked bream in the intestinal phase. The data in Table 1 indicates that the concentrations of $\mathrm{Mn}$ and $\mathrm{As}$ are lower in cooked bream than in raw bream. Conversely, $\mathrm{Ni}$ and $\mathrm{Cu}$ concentrations are lower for cooked bream in the intestinal phase in September. The concentrations of As, $\mathrm{Fe}, \mathrm{Ni}$ and $\mathrm{Se}$ are lower for cooked bream than for raw bream in March. Only the concentration of $\mathrm{Cu}$ is higher in cooked bream.

For anchovy, $\mathrm{P}$ values of the concentrations of these elements for raw and cooked anchovies in the gastric phase were lower than 0.05 for $\mathrm{Fe}, \mathrm{Co}, \mathrm{Mn}, \mathrm{Ni}$, Se and $\mathrm{Ti}$ in September and for As, Co, Cu, Fe, Mn, Se and $\mathrm{Ti}$ in March. Therefore, significant differences were observed for these analytes between raw and cooked anchovies in the gastric phase. The results given in Table 1 show that the concentrations of these elements are lower in cooked anchovy than in the raw anchovy. The exception is $\mathrm{Cu}$ in March. The P values for As, $\mathrm{Co}, \mathrm{Cu}, \mathrm{Fe}, \mathrm{Mn}, \mathrm{Ni}$, $\mathrm{Se}$ and Ti in September and As, Cu, Se and Ti for March in the intestinal phase extracts of anchovy are lower than 0.05 indicating that significant differences exist between the concentrations of these elements in the intestinal phase. The bioaccessible concentrations of these elements are lower for cooked anchovy than raw anchovy except for $\mathrm{Ni}$ in September and Cu for March.

$\mathrm{P}$ values were lower than 0.05 for $\mathrm{As}, \mathrm{Co}, \mathrm{Cu}, \mathrm{Fe}, \mathrm{Mn}$, and Se for September and As, Co, Fe, Mn, Ni, Se, and Ti for
March in the gastric phase of horse mackerel. As shown in Table 1, the concentrations of the majority of these elements, except for $\mathrm{Cu}, \mathrm{Mn}$ and $\mathrm{Ti}$ in September are higher for raw mackerel than cooked mackerel. For the intestinal phase, $P$ values were calculated from the results of the concentrations of the elements in raw and cooked mackerel. Significant differences were obtained between raw and cooked mackerel for $\mathrm{Fe}, \mathrm{Mn}, \mathrm{Ni}$ and $\mathrm{Se}$ in September and As, Co, Fe, Se, Ni and Ti in March. The concentrations of these elements with the exceptions of $\mathrm{Mn}$ and $\mathrm{Ni}$ in September and $\mathrm{As}, \mathrm{Fe}, \mathrm{Co}$ and $\mathrm{Ni}$ were lower for cooked horse mackerel than raw horse mackerel.

For the gastric phase extractions of seabass, the concentrations of $\mathrm{Co}, \mathrm{Cu}, \mathrm{Fe}, \mathrm{Ni}$ and $\mathrm{Se}$ in September and $\mathrm{Co}, \mathrm{Ni}, \mathrm{Se}$ and $\mathrm{Ti}$ in March were significantly different between raw and cooked seabass. In raw seabass the concentrations of these elements (except for $\mathrm{Cu}$ and $\mathrm{Ni}$ in September), were higher than cooked seabass. These data are also shown in Table 1 . In the intestinal phase extractions of seabass, the $\mathrm{P}$ values for $\mathrm{Co}, \mathrm{Cu}, \mathrm{Mn}, \mathrm{Ni}$ and $\mathrm{Se}$ in September were lower than 0.05 indicating significant differences. With the exception of $\mathrm{Mn}$, the concentrations of these elements in September were lower for cooked seabass than for raw seabass. In March, no significant differences in the concentrations of any of the elements between raw and cooked fish were found in the intestinal phase extracts.

$P$ values for sardines in the gastric phase were lower than 0.05 for $\mathrm{As}, \mathrm{Fe}, \mathrm{Cu}, \mathrm{Co}, \mathrm{Mn}, \mathrm{Ni}, \mathrm{Se}$ and $\mathrm{Ti}$, in September and for As, Co, Fe, Mn, Se and Ti, in March; indicating significant differences. With the exception if $\mathrm{Ni}$ in September, the analyte concentrations were higher in raw sardines than in cooked (Table 1). Significant differences in the concentrations of As, Co, $\mathrm{Cu}, \mathrm{Fe}, \mathrm{Mn}$, Se and Ti in September and for Fe and $\mathrm{Mn}$ in March were observed when the sardines were cooked. The concentrations of these elements (except $\mathrm{Mn}$ in March) were higher in raw sardines than in cooked sardines (Table 1).

In the gastric phase extractions of the whiting, significant differences were observed in the concentrations of As, Co, Se and Ti in September and As, $\mathrm{Mn}, \mathrm{Ni}$, Se and Ti in March between raw and cooked fish. These analytes' concentrations were higher in raw whiting than in the cooked (Table 1). For the intestinal phase extractions, $P$ values were lower than 0.05 for As, $\mathrm{Co}, \mathrm{Cu}, \mathrm{Mn}$ and $\mathrm{Ti}$ in September and for $\mathrm{Cu}$ and $\mathrm{Fe}$ in March. The data in Table 1 also indicate that, with the exception of $\mathrm{Co}$ and $\mathrm{Mn}$ in September and of $\mathrm{Cu}$ and $\mathrm{Fe}$ in March, the concentrations were higher in the intestinal phase extracts from raw whiting than when it had been cooked.

From ANOVA, it can be seen that the elemental concentrations in the gastric and intestinal phases for both September and March decrease when the different types of fish are cooked. Similar findings have been observed for $\mathrm{Hg}$, Se and methylmercury (MeHg) bioaccessibility in Tuna that was grilled or in canned 
Table 1. Concentrations of elements obtained using total digestion and the in-vitro gastro intestinal experiments in fish (mean and Standard deviation, $\mathrm{N}=3$ )

\begin{tabular}{|c|c|c|c|c|c|c|c|c|c|}
\hline & & & & RAW & & & COOKED & & \\
\hline & & & $\begin{array}{l}\text { Total* } \\
\left(\mu g \mathrm{~kg}^{-1}\right)\end{array}$ & $\begin{array}{l}\text { Gastric } \\
\left(\mu \mathrm{kg}^{-1}\right)\end{array}$ & $\begin{array}{c}\text { Intestinal } \\
\left(\mu \mathrm{kg}^{-1}\right)\end{array}$ & BA\%* & $\begin{array}{l}\text { Gastric } \\
\left(\mu \mathrm{kg}^{-1}\right)\end{array}$ & $\begin{array}{c}\text { Intestinal } \\
\left(\mu \mathrm{kg}^{-1}\right)\end{array}$ & BA\%* \\
\hline \multirow{14}{*}{ 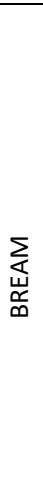 } & \multirow{9}{*}{ 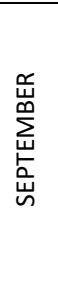 } & $\mathrm{Ti}$ & $325.34 \pm 2.50$ & $185.36 \pm 11.56$ & $408.32 \pm 97.46$ & 125.5 & $154.29 \pm 17.70$ & $263.93 \pm 19.50$ & 81.12 \\
\hline & & $\mathrm{Mn}$ & $158.24 \pm 64.96$ & $46.31 \pm 19.97$ & $4.93 \pm 0.34$ & 3.12 & $41.98 \pm 6.26$ & $14.13 \pm 0.62$ & 8.93 \\
\hline & & $\mathrm{Fe}$ & $4839.20 \pm 2.75$ & $<\mathrm{LOD}^{*}$ & $660.46 \pm 25.86$ & 13.65 & $<\mathrm{LOD}^{*}$ & $732.12 \pm 107.80$ & 15.13 \\
\hline & & Co & $26.45 \pm 1.56$ & $3.14 \pm 0.33$ & $2.79 \pm 0.27$ & 10.53 & $1.54 \pm 0.18$ & $1.61 \pm 0.77$ & 6.09 \\
\hline & & $\mathrm{Ni}$ & $44.82 \pm 1.38$ & $1.29 \pm 0.01$ & $8.11 \pm 1.20$ & 18.09 & $2.14 \pm 0.08$ & $<$ LOD $^{*}$ & - \\
\hline & & $\mathrm{Cu}$ & $381.70 \pm 120.03$ & $23.30 \pm 12.85$ & $242.00 \pm 1.12$ & 63.40 & $17.88 \pm 3.88$ & $66.49 \pm 4.23$ & 17.42 \\
\hline & & As & $611.26 \pm 23.89$ & $625.62 \pm 22.77$ & $380.46 \pm 9.19$ & 62.24 & $\mathrm{ND}^{*}$ & $649.75 \pm 0.66$ & 106.30 \\
\hline & & Se & $179.31 \pm 0.94$ & $61.84 \pm 5.07$ & $53.97 \pm 6.17$ & 30.10 & $10.87 \pm 1.96$ & $46.72 \pm 5.78$ & 26.05 \\
\hline & & $\mathrm{Ti}$ & $410.51 \pm 27.66$ & $248.43 \pm 14.44$ & $\mathrm{ND}^{*}$ & - & $109.90 \pm 17.82$ & $344.23 \pm 22.21$ & 83.85 \\
\hline & \multirow{6}{*}{$\begin{array}{l}\text { I } \\
\substack{\mathbb{Z} \\
\Sigma} \\
\sum\end{array}$} & $\mathrm{Mn}$ & $101.09 \pm 9.50$ & $13.57 \pm 5.58$ & $<L^{\prime}{ }^{*}$ & - & $13.45 \pm 3.93$ & $<$ LOD $^{*}$ & - \\
\hline & & $\mathrm{Fe}$ & $2856.0 \pm 159.2$ & $<\mathrm{LOD}^{*}$ & $2770.6 \pm 387.7$ & 97.01 & $<$ LOD $^{*}$ & $1487.8 \pm 65.1$ & 52.09 \\
\hline & & Co & $5.63 \pm 0.95$ & $2.40 \pm 0.27$ & $<L^{*}{ }^{*}$ & - & $0.95 \pm 0.19$ & $<$ LOD $^{*}$ & - \\
\hline & & $\mathrm{Ni}$ & $30.13 \pm 1.15$ & $2.87 \pm 0.62$ & $6.44 \pm 2.03$ & 21.37 & $<\mathrm{LOD}^{*}$ & $<\mathrm{LOD}^{*}$ & - \\
\hline & & $\mathrm{Cu}$ & $293.62 \pm 35.44$ & $<\mathrm{LOD}^{*}$ & $96.23 \pm 27.29$ & 32.77 & $<$ LOD* $^{*}$ & $251.8 \pm 13.3$ & 85.75 \\
\hline \multirow{20}{*}{$\begin{array}{l}\circlearrowright \\
\text { 온 } \\
\text { ¿ }\end{array}$} & & As & $665.34 \pm 34.38$ & $649.07 \pm 34.30$ & $629.55 \pm 6.08$ & 94.62 & $280.72 \pm 33.75$ & $558.21 \pm 33.27$ & 83.90 \\
\hline & \multirow{9}{*}{ 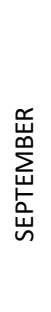 } & $\mathrm{Se}$ & $156.19 \pm 6.13$ & $54.06 \pm 4.96$ & $24.14 \pm 3.18$ & 15.45 & $4.10 \pm 1.92$ & $<\mathrm{LOD}^{*}$ & - \\
\hline & & $\mathrm{Ti}$ & $462.35 \pm 9.62$ & $250.88 \pm 2.69$ & $467.08 \pm 16.99$ & 101.02 & $169.37 \pm 9.93$ & $245.62 \pm 17.84$ & 53.12 \\
\hline & & $\mathrm{Mn}$ & $961.51 \pm 70.88$ & $344.52 \pm 70.99$ & $77.30 \pm 1.02$ & 8.04 & $137.62 \pm 15.18$ & $3.06 \pm 1.72$ & 0.32 \\
\hline & & $\mathrm{Fe}$ & $12510.6 \pm 388.0$ & $987.62 \pm 4.34$ & $1662.4 \pm 73.3$ & 13.29 & $88.70 \pm 15.37$ & $251.71 \pm 88.94$ & 2.01 \\
\hline & & Co & $32.53 \pm 1.01$ & $6.63 \pm 0.51$ & $5.30 \pm 0.08$ & 16.29 & $3.33 \pm 0.32$ & $2.67 \pm 0.19$ & 8.21 \\
\hline & & $\mathrm{Ni}$ & $83.93 \pm 2.49$ & $26.19 \pm 1.15$ & $10.18 \pm 1.28$ & 12.13 & $15.44 \pm 0.73$ & $15.16 \pm 0.62$ & 18.07 \\
\hline & & $\mathrm{Cu}$ & $1131.07 \pm 72.15$ & $219.70 \pm 57.10$ & $608.18 \pm 53.90$ & 53.77 & $161.16 \pm 1.84$ & $233.79 \pm 21.99$ & 20.67 \\
\hline & & As & $6235.95 \pm 206.15$ & ND* & $4138.9 \pm 48.1$ & 66.37 & $5338.4 \pm 556.6$ & $2749.1 \pm 198.6$ & 44.08 \\
\hline & & $\mathrm{Se}$ & $366.58 \pm 4.29$ & $119.81 \pm 7.21$ & $135.34 \pm 6.32$ & 36.92 & $40.73 \pm 4.33$ & $47.21 \pm 19.85$ & 12.88 \\
\hline & \multirow{8}{*}{ 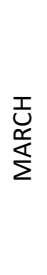 } & $\mathrm{Ti}$ & $346.51 \pm 27.01$ & $181.14 \pm 34.55$ & $334.65 \pm 66.34$ & 96.58 & $61.61 \pm 10.26$ & $227.51 \pm 40.91$ & 65.66 \\
\hline & & $\mathrm{Mn}$ & $359.47 \pm 81.80$ & $226.42 \pm 43.19$ & $28.59 \pm 22.84$ & 7.95 & $77.01 \pm 12.83$ & $60.73 \pm 10.88$ & 16.90 \\
\hline & & $\mathrm{Fe}$ & $4970.29 \pm 548.04$ & $575.98 \pm 7.45$ & $2071.6 \pm 842.1$ & 41.68 & $<\mathrm{LOD}^{*}$ & $3462.77 \pm 282.35$ & 69.67 \\
\hline & & Co & $6.04 \pm 0.79$ & $1.83 \pm 0.34$ & $<L^{*} D^{*}$ & - & $1.09 \pm 0.16$ & $<\mathrm{LOD}^{*}$ & - \\
\hline & & $\mathrm{Ni}$ & $28.76 \pm 1.26$ & $4.60 \pm 0.05$ & $12.38 \pm 0.92$ & 43.03 & $4.60 \pm 1.39$ & $12.25 \pm 0.66$ & 42.59 \\
\hline & & $\mathrm{Cu}$ & $1419.11 \pm 44.83$ & $<\mathrm{LOD}^{*}$ & $620.13 \pm 3.34$ & 43.70 & $342.82 \pm 2.49$ & $1145.94 \pm 97.75$ & 80.75 \\
\hline & & As & $6152.92 \pm 402.57$ & $4905.2 \pm 285.3$ & $5274.9 \pm 421.0$ & 85.73 & $3790.1 \pm 499.6$ & $2394.0 \pm 200.5$ & 38.91 \\
\hline & & $\mathrm{Se}$ & $227.91 \pm 85.35$ & $116.40 \pm 6.50$ & $204.84 \pm 22.59$ & 90.0 & $6.98 \pm 1.37$ & $60.18 \pm 11.88$ & 26.41 \\
\hline & \multirow{8}{*}{ 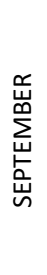 } & $\mathrm{Ti}$ & $375.36 \pm 4.15$ & $168.75 \pm 4.46$ & $292.90 \pm 9.65$ & 78.03 & $171.70 \pm 20.52$ & $322.36 \pm 65.79$ & 85.88 \\
\hline & & $\mathrm{Mn}$ & $361.66 \pm 36.61$ & $30.44 \pm 1.62$ & $<\mathrm{LOD}^{*}$ & - & $48.74 \pm 7.80$ & $20.02 \pm 0.82$ & 5.54 \\
\hline \multirow{12}{*}{ 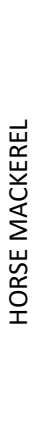 } & & $\mathrm{Fe}$ & $8559.2 \pm 183.8$ & $339.23 \pm 41.98$ & $1348.6 \pm 138.6$ & 15.76 & $<\mathrm{LOD}$ & $998.4 \pm 119.5$ & 11.67 \\
\hline & & Co & $29.76 \pm 1.65$ & $3.93 \pm 0.21$ & $3.51 \pm 0.43$ & 11.81 & $2.50 \pm 0.50$ & $3.43 \pm 0.64$ & 11.52 \\
\hline & & $\mathrm{Ni}$ & $69.44 \pm 4.11$ & $14.16 \pm 1.36$ & $3.00 \pm 1.47$ & 4.30 & $12.69 \pm 3.09$ & $13.04 \pm 3.60$ & 18.78 \\
\hline & & $\mathrm{Cu}$ & $723.18 \pm 13.42$ & $106.25 \pm 23.70$ & $257.26 \pm 16.41$ & 35.57 & $161.32 \pm 12.30$ & $269.30 \pm 61.11$ & 37.24 \\
\hline & & As & $1228.60 \pm 0.16$ & $770.63 \pm 26.43$ & $619.82 \pm 27.59$ & 50.45 & $621.31 \pm 35.28$ & $546.63 \pm 81.27$ & 44.49 \\
\hline & & $\mathrm{Se}$ & $483.64 \pm 6.77$ & $153.03 \pm 10.55$ & $216.70 \pm 0.34$ & 44.81 & $61.55 \pm 0.63$ & $107.40 \pm 10.82$ & 22.21 \\
\hline & \multirow{7}{*}{ 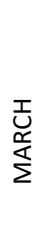 } & $\mathrm{Ti}$ & $708.65 \pm 98.68$ & $261.49 \pm 37.16$ & $378.58 \pm 16.18$ & 53.42 & $158.41 \pm 12.97$ & $282.62 \pm 16.01$ & 39.88 \\
\hline & & $\mathrm{Mn}$ & $135.51 \pm 4.44$ & $53.18 \pm 19.51$ & $<$ LOD $^{*}$ & - & $1.67 \pm 0.37$ & $<L^{\prime}{ }^{*}$ & - \\
\hline & & $\mathrm{Fe}$ & $3945.4 \pm 445.6$ & $285.31 \pm 40.40$ & $1168.2 \pm 1159.3$ & 13.30 & $<$ LOD $^{*}$ & $2406.25 \pm 226.30$ & 60.99 \\
\hline & & Co & $5.27 \pm 0.56$ & $4.78 \pm 0.44$ & $<\mathrm{LOD}^{*}$ & - & $0.93 \pm 0.09$ & $1.34 \pm 0.81$ & 25.37 \\
\hline & & $\mathrm{Ni}$ & $45.57 \pm 7.27$ & $40.37 \pm 3.79$ & $<\mathrm{LOD}^{*}$ & - & $1.61 \pm 0.23$ & $12.92 \pm 4.51$ & 28.35 \\
\hline & & $\mathrm{Cu}$ & $330.58 \pm 22.35$ & $<\mathrm{LOD}^{*}$ & $129.33 \pm 78.85$ & 39.12 & $<\mathrm{LOD}^{*}$ & $240.06 \pm 122.15$ & 72.62 \\
\hline \multirow{18}{*}{ 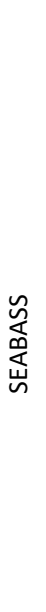 } & & As & $4077.2 \pm 899.2$ & $3260.5 \pm 22.7$ & $2202.7 \pm 143.4$ & 54.03 & $1339.2 \pm 103.2$ & $2768.0 \pm 170.8$ & 67.89 \\
\hline & \multirow{17}{*}{ 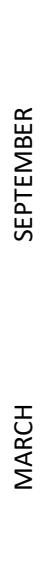 } & $\mathrm{Se}$ & $372.37 \pm 76.44$ & $195.17 \pm 29.04$ & $164.57 \pm 10.17$ & 44.20 & $24.78 \pm 9.11$ & $82.89 \pm 4.49$ & 22.26 \\
\hline & & $\mathrm{Ti}$ & $412.22 \pm 90.66$ & $145.35 \pm 10.55$ & $336.11 \pm 37.69$ & 81.54 & $134.78 \pm 2.82$ & $268.89 \pm 26.80$ & 65.22 \\
\hline & & $\mathrm{Mn}$ & $433.10 \pm 48.09$ & $46.01 \pm 0.94$ & $3.24 \pm 0.98$ & 0.75 & $44.55 \pm 7.11$ & $29.76 \pm 8.50$ & 6.87 \\
\hline & & $\mathrm{Fe}$ & $4087.9 \pm 564.0$ & $67.83 \pm 22.35$ & $617.73 \pm 1.69$ & 15.11 & $<$ LOD $^{*}$ & $548.98 \pm 95.81$ & 50.46 \\
\hline & & Co & $18.31 \pm 0.46$ & $3.65 \pm 0.10$ & $5.12 \pm 0.66$ & 25.97 & $1.81 \pm 0.09$ & $3.10 \pm 0.53$ & 16.93 \\
\hline & & $\mathrm{Ni}$ & $79.29 \pm 28.64$ & $2.37 \pm 0.16$ & $5.06 \pm 0.69$ & 6.38 & $3.38 \pm 0.25$ & $<\mathrm{LOD}^{*}$ & - \\
\hline & & $\mathrm{Cu}$ & $348.84 \pm 8.63$ & $<\mathrm{LOD}$ & $191.22 \pm 21.20$ & 54.82 & $1.91 \pm 0.13$ & $47.71 \pm 4.15$ & 13.68 \\
\hline & & As & $273.06 \pm 16.93$ & $259.05 \pm 22.12$ & $168.15 \pm 10.22$ & 61.58 & $232.07 \pm 3.31$ & $174.60 \pm 4.45$ & 63.94 \\
\hline & & $\mathrm{Se}$ & $160.21 \pm 0.84$ & $49.81 \pm 7.40$ & $63.18 \pm 7.66$ & 39.43 & $7.99 \pm 2.12$ & $22.03 \pm 1.64$ & 13.75 \\
\hline & & $\mathrm{Ti}$ & $407.22 \pm 39.42$ & $253.88 \pm 48.99$ & $436.77 \pm 114.61$ & 107.25 & $164.29 \pm 12.86$ & $355.57 \pm 87.03$ & 87.32 \\
\hline & & $\mathrm{Mn}$ & $124.01 \pm 40.53$ & $<L O D$ & $5.43 \pm 0.11$ & 4.38 & $20.69 \pm 4.99$ & $20.96 \pm 12.26$ & 16.90 \\
\hline & & $\mathrm{Fe}$ & $2260.3 \pm 381.1$ & $<\mathrm{LOD}^{*}$ & $1742.6 \pm 51.3$ & 77.10 & $<$ LOD $^{*}$ & $1776.0 \pm 117.9$ & 78.58 \\
\hline & & Co & $4.59 \pm 0.38$ & $1.55 \pm 0.02$ & $<\mathrm{LOD}^{*}$ & - & $0.52 \pm 0.02$ & $<\mathrm{LOD}^{*}$ & - \\
\hline & & $\mathrm{Ni}$ & $32.54 \pm 9.52$ & $1.23 \pm 0.28$ & $<\mathrm{LOD}^{*}$ & - & $<L O D$ & $<L^{\prime}{ }^{*}$ & - \\
\hline & & $\mathrm{Cu}$ & $319.71 \pm 77.02$ & $<\mathrm{LOD}^{*}$ & $105.52 \pm 22.96$ & 33.00 & $<$ LOD $^{*}$ & $165.58 \pm 51.15$ & 51.79 \\
\hline & & As & $296.57 \pm 10.08$ & $298.40 \pm 80.25$ & $294.33 \pm 34.12$ & 99.24 & $190.44 \pm 0.84$ & $237.65 \pm 10.14$ & 80.13 \\
\hline & & $\mathrm{Se}$ & $121.89 \pm 33.63$ & $63.36 \pm 6.50$ & $27.50 \pm 7.20$ & 38.90 & $7.40 \pm 1.54$ & $41.63 \pm 1.26$ & 34.15 \\
\hline
\end{tabular}


Table 1. Continued

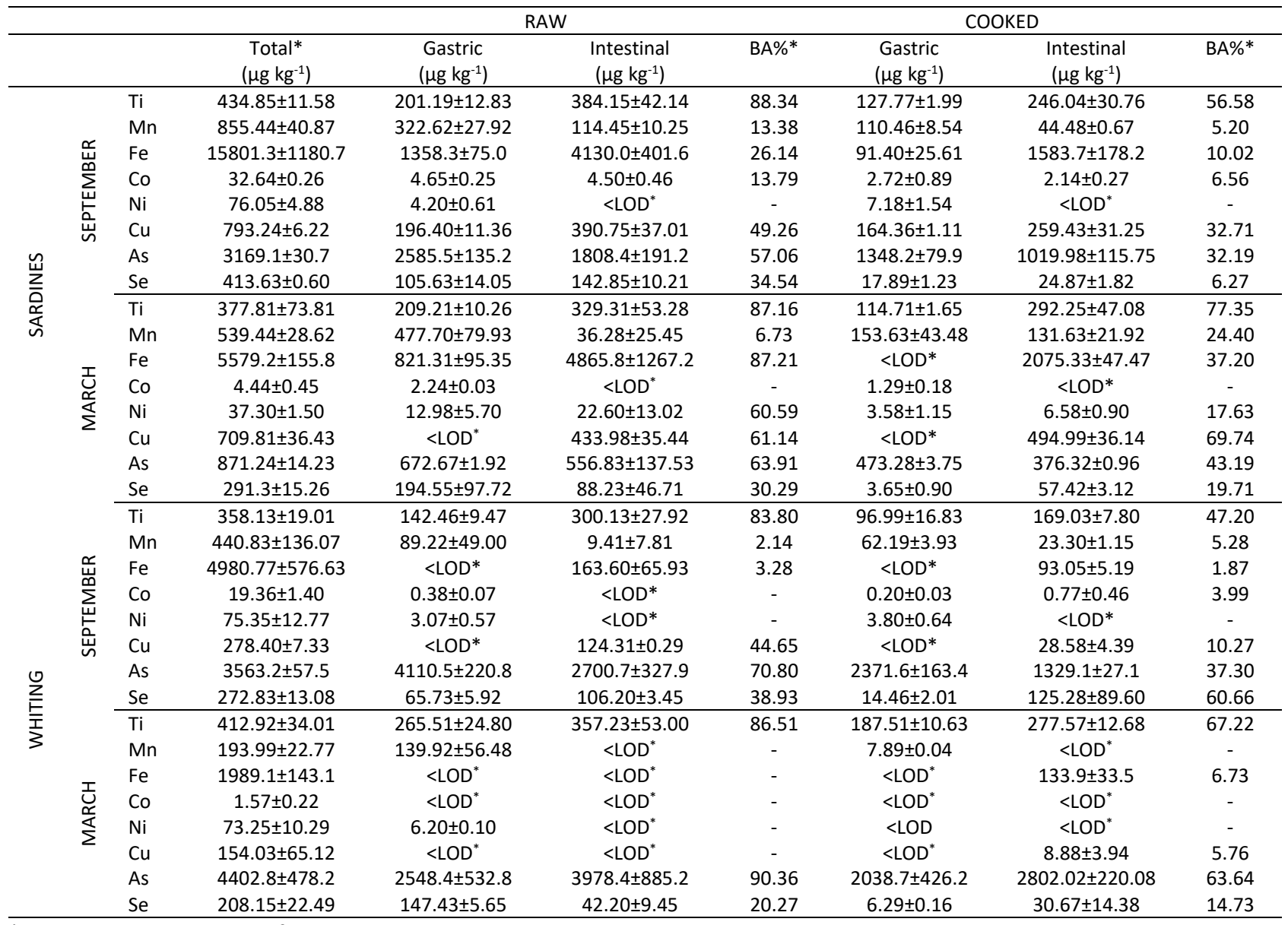

*These data were obtained from Güngör and Kara, 2018.

$\angle \mathrm{LOD}=$ Under limits of detection.

tuna which were also found to have lower concentrations of $\mathrm{Hg}$, Se and $\mathrm{MeHg}$ than raw tuna (Afonso et al. 2015). This result had been connected with protein denaturation during cooking and canning which causes lower bioaccessibility. Cooking methods, e.g. grilling have been found to be an efficient way of reducing the oral bioaccessibility of $\mathrm{Ag}, \mathrm{Cd}, \mathrm{Cu}, \mathrm{Pb}$, and Zn from oysters (Gao \&Wang. 2014). The same conclusion has been reached in other research studies (Ouedraogo \& Amyot. 2011; He et al. 2010).

\section{The Effect of the Season on the Bioaccessibility of the Elements}

A previous investigation was performed to determine whether or not there is a relationship between the elements' total contents and the amount of fat in fish. The total elemental concentration and fat contents in the fish samples were compared in March and in September. The results of that work showed that a significant temporal difference existed in elemental concentration. However, no relationship was found to the seasonal variation in fat concentrations (Güngör \& Kara. 2018). The present study was undertaken to investigate whether or not the fat content of the fish, which is related to the season, affects the bioaccessibility of the analytes. The elemental data in the extract solutions obtained from the raw and cooked fish in both September and March were tested using one-way ANOVA.

For gastric phase extracts of bream, a significant difference was observed between the concentrations of $\mathrm{Co}, \mathrm{Cu}, \mathrm{Ni}$ and $\mathrm{Ti}$ in raw fish and $\mathrm{Co}, \mathrm{Cu}, \mathrm{Mn}, \mathrm{Ni}$ and $\mathrm{Se}$ in cooked bream between March and September. The data in Table 1 demonstrates that the concentrations of most of these elements (with the exception of $\mathrm{Ti}$ and $\mathrm{Ni}$ from raw bream), are higher in September than they were in March. The $\mathrm{P}$ values of $\mathrm{As}, \mathrm{Co}, \mathrm{Cu}, \mathrm{Fe}, \mathrm{Mn}$ and $\mathrm{Se}$ in raw bream and $\mathrm{As}, \mathrm{Co}, \mathrm{Cu}, \mathrm{Fe}, \mathrm{Mn}$, Se and $\mathrm{Ti}$ in cooked bream for the intestinal phases in March and September were smaller than 0.05 . This indicates a significant difference between their concentrations in intestinal phase extracts from bream in March and September for raw and cooked fish. As shown in Table 1, the concentrations of most of these elements, except for As and Fe in raw bream and $\mathrm{Cu}, \mathrm{Fe}$ and $\mathrm{Ti}$ in cooked bream, were higher in September than they were in March. This shows that these elements are more bioaccessible in September when the bream is generally fattier. This is in agreement 
with previous work (Ekovitrin.com. 2015; Güngör \& Kara. 2018).

The $\mathrm{P}$ values found for $\mathrm{Co}, \mathrm{Cu}, \mathrm{Fe}, \mathrm{Mn}, \mathrm{Ni}$ and $\mathrm{Ti}$ in raw anchovy and $\mathrm{As}, \mathrm{Co}, \mathrm{Cu}, \mathrm{Fe}, \mathrm{Mn}, \mathrm{Ni}$, Se and $\mathrm{Ti}$ in cooked anchovy for gastric phase extractions of fish in March and September were lower than 0.05 indicating a significant difference in the concentrations. For intestinal phase extractions of the anchovy, significant differences in the concentrations of $\mathrm{As}, \mathrm{Co}, \mathrm{Mn}$, Se and $\mathrm{Ti}$ in raw anchovy and $\mathrm{Mn}, \mathrm{Fe}, \mathrm{Co}, \mathrm{Ni}$ and $\mathrm{Cu}$ in cooked anchovy were observed between March and September. Therefore, Table 1 shows that the concentrations of these elements, except for $\mathrm{Cu}$ in cooked anchovy for gastric phase and As and Se in raw anchovy and $\mathrm{Mn}, \mathrm{Fe}$ and $\mathrm{Cu}$ in cooked anchovy for intestinal phases, were higher in September than March. Comparison of the bioaccessibility of the elements in the intestinal phases indicates that it is greater in March. This is when the anchovy contains more fat (Ekovitrin.com. 2015; Güngör \& Kara. 2018).

For gastric phase extractions of horse mackerel, significant differences were found between March and September in the concentrations of $\mathrm{As}, \mathrm{Co}, \mathrm{Cu}, \mathrm{Ni}$ and $\mathrm{Ti}$ in the raw product. Similarly, gastric phase extractions yielded significant differences in $\mathrm{As}, \mathrm{Co}, \mathrm{Cu}, \mathrm{Mn}, \mathrm{Ni}$, and Se in the cooked horse mackerel between the two dates. Intestinal phase extractions demonstrated significant differences in concentration of $\mathrm{As}, \mathrm{Co}, \mathrm{Fe}$, Se and $\mathrm{Ti}$ in the raw material and of $\mathrm{As}, \mathrm{Co}, \mathrm{Fe}, \mathrm{Mn}$ and $\mathrm{Se}$ in cooked mackerel in March and September. The concentrations of many of these elements, with the exception of As, Co, $\mathrm{Ni}$ and $\mathrm{Ti}$, in the raw horse mackerel and $\mathrm{As}$ in cooked horse mackerel in gastric phase, and for As in raw horse mackerel and Fe and As in cooked horse mackerel for intestinal phases are higher in September than March. The results in Table 1 show that most of these elements have higher bioaccessible percentages in March when the horse mackerel contains significantly more fat (Ekovitrin.com, 2015; Güngör \& Kara. 2018).

There were significant differences in concentrations of $\mathrm{Co}, \mathrm{Fe}, \mathrm{Ni}$ and $\mathrm{Ti}$ in the gastric phase extractions from raw seabass between March and September. Similarly, $\mathrm{As}, \mathrm{Co}, \mathrm{Cu}, \mathrm{Mn}, \mathrm{Ni}$ and $\mathrm{Ti}$ in gastric phase extractions from cooked seabass also showed significant differences between March and September. In addition, As, Co, Cu, $\mathrm{Fe}, \mathrm{Mn}, \mathrm{Ni}$ and Se concentrations in raw seabass and $\mathrm{As}$, $\mathrm{Co}, \mathrm{Cu}, \mathrm{Fe}$ and Se concentrations in cooked seabass in the intestinal phase extracts differed significantly between March and September. In the gastric phase extracts, the concentrations of these elements (with the exception of $\mathrm{Ti}$ in both raw and cooked seabass) were higher in September. Similarly, for the intestinal extracts, $\mathrm{Mn}$ and $\mathrm{Fe}$ in the raw seabass and $\mathrm{As}, \mathrm{Cu}, \mathrm{Fe}$ and $\mathrm{Se}$ in cooked seabass were also higher in September. Interestingly, the seabass should contain less fat in September (Ekovitrin.com 2015), than in March as given as Table 1. However, the seabass used in this work were obtained from a fish farm rather than being caught from the wild. As stated previously, no significant difference in the fat content between September and March was found (Güngör \& Kara. 2018).

There were significant differences in the bioaccessible concentrations of $\mathrm{As}, \mathrm{Co}, \mathrm{Cu}, \mathrm{Fe}$ and $\mathrm{Mn}$ in the gastric phase extractions from raw sardines between the two months. Similarly, As, $\mathrm{Cu}, \mathrm{Fe}, \mathrm{Ni}$, Se and $\mathrm{Ti}$ in cooked sardines also had significant concentration differences between the two months in the gastric phase extractions. For the intestinal phase, $\mathrm{As}, \mathrm{Co}, \mathrm{Mn}$ and $\mathrm{Ni}$ for raw sardines and $\mathrm{As}, \mathrm{Co}, \mathrm{Cu}, \mathrm{Fe}, \mathrm{Mn}, \mathrm{Ni}$ and $\mathrm{Se}$ in cooked sardines showed significant differences in concentration between September and March. Table 1 shows that the concentrations of these elements, except for $\mathrm{Mn}$ for raw sardines in the gastric phase and for $\mathrm{Ni}$ in raw sardines and $\mathrm{Cu}, \mathrm{Fe}, \mathrm{Mn}, \mathrm{Ni}$, and $\mathrm{Se}$ in cooked sardines in the intestinal phase, are higher in September. The sardine contains more fat in September (Ekovitrin.com, 2015; Güngör \& Kara. 2018).

The $P$ values obtained for the concentrations of $\mathrm{As}, \mathrm{Co}$, $\mathrm{Ni}, \mathrm{Se}$, and $\mathrm{Ti}$ in raw whiting and for $\mathrm{Co}, \mathrm{Mn}, \mathrm{Ni}$, Se and $\mathrm{Ti}$ in cooked whiting for the gastric phase extraction were less than 0.05 . This indicates a significant difference between September and March. For the intestinal phase, $\mathrm{Fe}, \mathrm{Cu}, \mathrm{Mn}$ and $\mathrm{Se}$ in raw whiting and As, $\mathrm{Co}, \mathrm{Cu}, \mathrm{Mn}$ and $\mathrm{Ti}$ in cooked whiting were significantly different between the two months. Table 1 shows that the concentrations of these elements, except for $\mathrm{Ni}$, Se and $\mathrm{Ti}$ in raw whiting and for $\mathrm{Ti}$ in cooked whiting in the gastric phase and for Ti and As in cooked whiting in the intestinal phases, are higher in September. The whiting generally contains less fat in September than in March (Ekovitrin.com, 2015; Güngör \& Kara. 2018). In previous work, no relationship was found between the total concentration of these analytes and the season in which the fish is fattier. The amounts of most of the analytes in each fish type in September were higher than in March. It would therefore appear that the season is more effective on the accumulation of these analytes in the fish muscle than the fat content. The present study has also shown that the bioaccessible concentrations of most of the analytes in gastric and intestinal extracts of fish are higher in September than in March (Ekovitrin.com, 2015; Güngör \& Kara. 2018).

\section{Principal Component Analyses}

Principal component analysis (PCA) was applied to all data obtained from gastric extractions and also from intestinal extractions in an attempt to interpret which elements are more bioaccesible in September or March and also whether cooking has an effect. Two principal components $(\mathrm{PC})$ having Eigen values higher than 1 were extracted from all data obtained from gastric phases in September and March. The first principal component extracted $50.6 \%$ and the second for $17.4 \%$ of the total variation of the data. The obtained loading and score values from gastric phase using PCA are given in a Supplemental file. The similarities between the 
elements and between the fish types from the point of view of the amounts of elements depending on whether the fish was raw or cooked and on the season, September and March in the gastric phase can be shown using PC loading and score graphs. The Figure $1 \mathrm{a}$ is the PCA loadings graph (PC 1-2) and Figure $1 \mathrm{~b}$ is two-way PCA score graph (PC 1-2). The elements were grouped according to their loading values in Figure $1 \mathrm{a}$ as:

Group 1 : Ni, Se, Ti,

Group 2 : As, Co, Cu, Fe, Mn.

Since the elements in the first group have higher scores on PC1 of the score graph given in Figure 1b, they have high concentrations in raw samples of anchovy in September and also raw samples of anchovy, horse mackerel, sardines and whiting in March. Of these samples, raw horse mackerel and sardines in March have the highest score values showing that they have the highest concentrations of first group elements. The second group elements have higher score values in raw and cooked samples of anchovy and horse mackerel in September and the cooked sample of anchovy in March as shown in Fig $1 \mathrm{~b}$. Therefore, these samples contain higher concentrations of second group elements in gastric extractions. The highest score value was observed for raw anchovy in September that shows this sample has highest concentrations of second group elements. In addition, these graphs (Figure $1 \mathrm{a}$ and b) indicate that cooked fish samples have lower concentrations of first and second group elements because they are present in the negative or low positive values on the axes. From these graphs, raw samples of anchovy, sardines and horse mackerel have higher positive values than other fish, indicating that the concentrations of the elements in these fish are higher than other fish. Therefore, these fish can be grouped for their elements bioaccessibility in the gastric phase extracts as:

Group 1: Anchovy, sardines, horse mackerel

Group 2: Seabass, whiting and bream

Three principal components having Eigen values higher than 1 were extracted from all data obtained from the intestinal phase extracts. The first principal component accounted for $33.1 \%$, the second for $19.6 \%$ of the total variation of the data and third principal component for 15.1 . Therefore, $67.8 \%$ of the total variation of data is explained by these components. The obtained loading and score values from intestinal phase using PCA are given in the Supplemental file. The PCA loadings graphs were given in the Figure 1c for PC 1-2 and the Figure 1e for PC 1-3. The PCA score graphs were given in the Figure $1 \mathrm{~d}$ for PC 1-2 and the Figure $1 \mathrm{f}$ for PC 1-3. The elements were grouped according to their loading values given in Fig $1 \mathrm{c}$ and Figure $1 \mathrm{e}$ :

Group 1 : $\mathrm{Fe}, \mathrm{Cu}, \mathrm{Mn}, \mathrm{Ni}$

Group 2 : As, Se

Group 3: Co

The similarities between the different fish from the point of view of the amounts of the elements depending on whether they are raw or cooked and on the season,
September or March in the intestinal phase extracts are shown using PC loading and score graphs in Figure 1. The PCA score graphs were given in the Figure 1d for PC 1-2 and the Figure if for PC 1-3. The first group elements have higher concentrations in raw samples of anchovy and sardines in September, and raw and cooked samples of anchovy and sardines in March (Figure 1d). This is because these elements have higher score values than others. The second group elements have higher score values in raw samples of anchovy, horse mackerel and whiting in September and March and in cooked anchovy in September (Figure 1d). Therefore, these intestinal extracts of samples contain higher concentrations of As and Se than other raw or cooked fishes in September or March. Higher score values were obtained for Co from raw samples of anchovy, sardines, horse mackerel and seabass and cooked samples of horse mackerel, sardines, whiting and seabass in September and cooked samples of sardines in March (Figure 1f). It can also be interpreted from these graphs (Figure 1c, 1d, 1e and 1f)) that data points for the cooked fish samples are seen in either the negative or the low positive values on the axes in these graphs. This means that they have lower concentrations of first and second group elements than raw fish samples. In general, anchovy, sardines and horse mackerel have higher positive score values than other fish. This indicates that the concentrations of the elements in intestinal extracts from these fish are higher than other fish types.

\section{Risk Assessments for Health}

Average fish consumption per capita in the world is 20.3 $\mathrm{kg}$ in 2016 (FAO, 2018). It is $24.3 \mathrm{~kg}$ for Europe (EUMOFA, 2018) and above $60 \mathrm{~kg}$ in Japan (Guillen, Natale, Carvalho, Casey, Hofherr, Druon, Fiore, Gibin, Zanzi, \& Martinsohn, 2019). Turkey stays behind the world average of consumption of fish with nearly 8 kilograms fish consumption per capita annually according to the report of Turkish Marine Research Foundation in 2017. However, this annual consumption of fish increases to $25.0 \mathrm{~kg} /$ person/year in the Black Sea region and nearly $0.5 \mathrm{~kg} /$ person/year in the Southeast regions of Turkey according to this report. Estimated Daily Intake (EDI) (mg $\mathrm{kg}^{-1}$ body weight day ${ }^{-1}$ ) of the different elements has been calculated using the data obtained from intestinal extracts for a person of $70 \mathrm{~kg}$ assuming $25 \mathrm{~kg}$ of fish consumption in the Black Sea region. Recommended dietary allowances (RDA) (mg/day) are 2.3 for male and 1.8 for female for $\mathrm{Mn}, 18$ for female and 8 for male for Fe, 0.9 for $\mathrm{Cu}, 0.055$ for Se and $0.104 \mu \mathrm{g} /$ day for Co (Given in the form of Vitamin B12 (equivalent to 2.4 $\mu \mathrm{g} /$ day Vitamin B12) (Rayman \& Callaghan. 2006). Reference oral dose (RfD) ( $\mathrm{mg} \mathrm{kg}^{-1} \mathrm{bw} /$ day) are given as 0.024 for $\mathrm{Mn}, 0.7$ for $\mathrm{Fe}, 0.01$ for $\mathrm{Co}, 0.02$ for $\mathrm{Ni}, 0.04$ for $\mathrm{Cu}, 0.005$ for Se and 0.0003 for As (JECFA, 2003; Department of Environmental Affairs, 2016).

Table 2 show that the calculated EDI values for all elements are lower than the RDA and RfD values except 


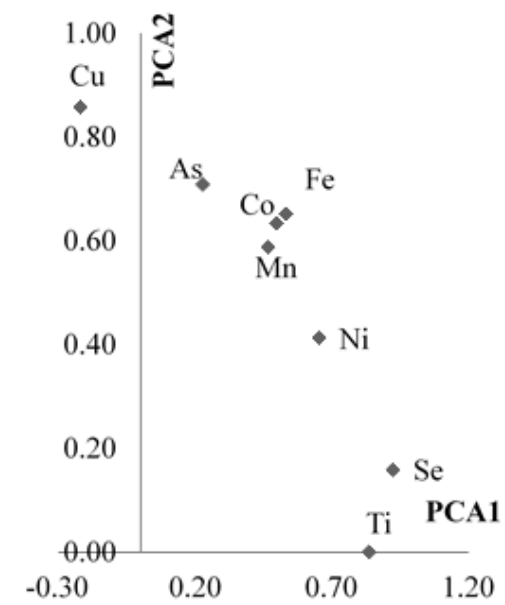

a) Loading graph

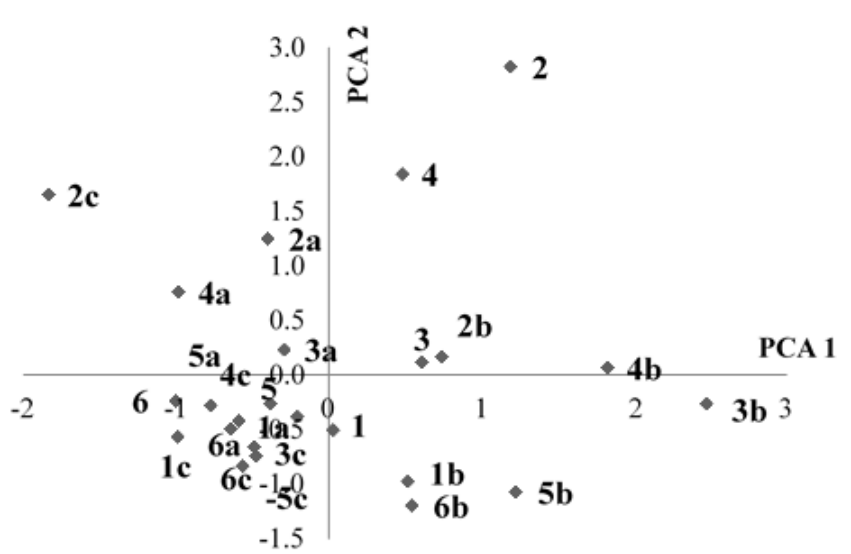

b) Score graph

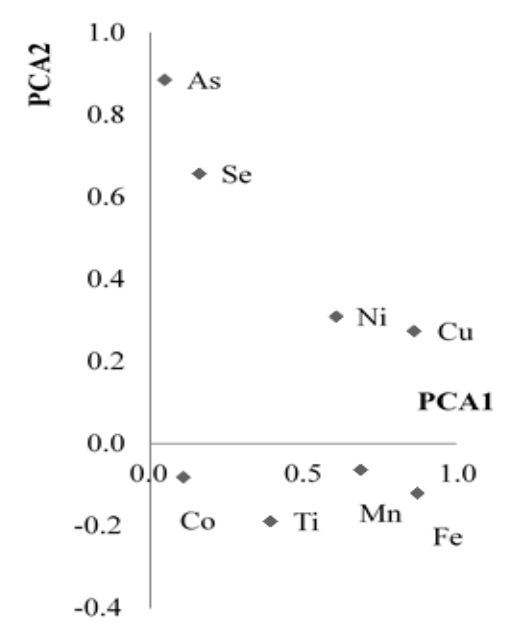

c) Loading graph

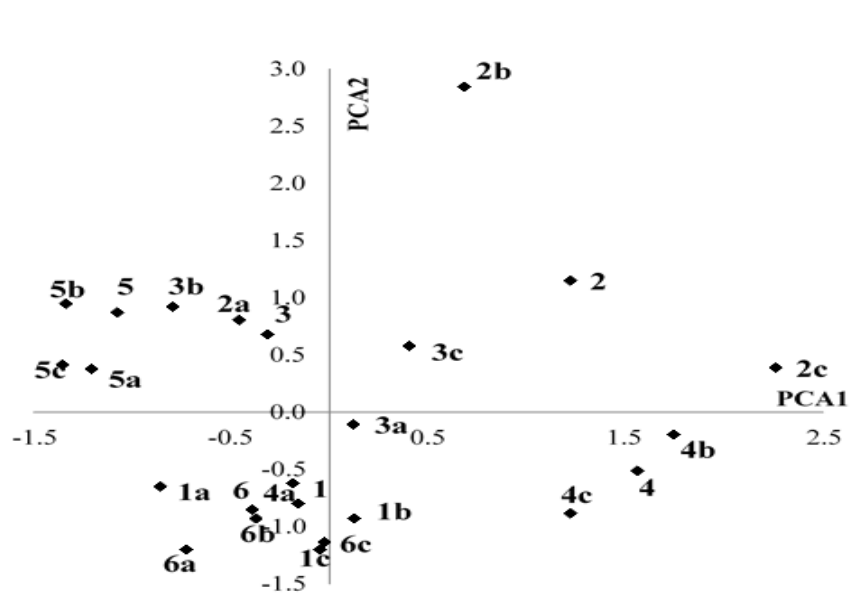

d) Score graph

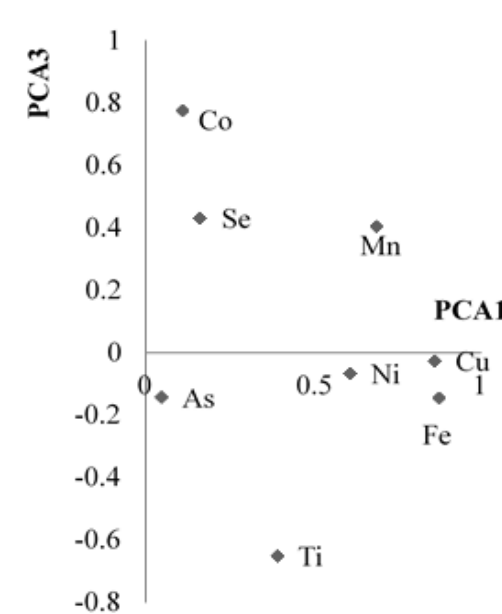

e) Loading graph

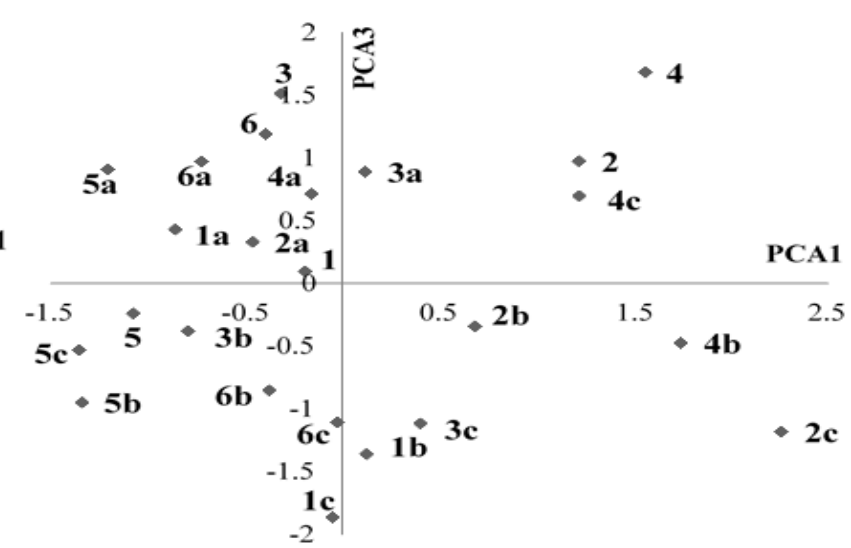

f) Score graph

Figure 1. Two way Principal component analysis loadings and score plots. $a$ and $b$ are for gastric ingestions and $c, d$, e and $f$ for intestinal ingestions (1. raw bream, 2. raw anchovy, 3. raw horse mackerel 4. raw sardine, 5. raw whiting, 6. raw seabass in September; 1a. cooked bream, 2 a. cooked anchovy, 3 a. cooked horse mackerel 4 a. cooked sardine, 5 a. cooked whiting, 6 a. cooked seabass in September; 1b. ra-w bream, 2b. raw anchovy, 3b. raw horse mackerel 4b. raw sardine, 5b. raw whiting, 6b. raw seabass in March; 1c. cooked bream, 2 c. cooked anchovy, 3 c. cooked horse mackerel 4 c. cooked sardine, 5 c. cooked whiting, 6 c. cooked seabass in March). 
for the values for As for cooked sardines and bream and raw whiting in September, which are higher than RfD values for As.

Inorganic arsenic compounds are known more hazardous to human health than the organic arsenic compounds e.g. arsenobetaine (Güngör \& Kara. 2018). The RfD value for As is given as the amount of inorganic As, that are known to be estimated as $10 \%$ of total As (Afonso et al. 2013; Medeirosa, Gobbo dos Santos, Goncalves, Bahia Braga, Krauss \& do Couto Jacob. 2014). Therefore, the estimated daily intake for As was given as this percentage of the total As in intestinal extracts in Table 2.

The Hazard Quotient (HQ) (Medeiros et al. 2014) for each element was also calculated. The Hazard Quotient was less than 1 for all elements studied with the exception of As in cooked sardines and bream and raw whiting in September (Table 3). In general, inorganic As represents $<10 \%$ of the total As content. If an assumption of $10 \%$ is made in this study, it may show a health risk through consuming fish. However, if this amount was lower, i.e. the inorganic As comprised < $10 \%$ of total As, then the Hazard Quotient would not necessarily be exceeded. No possible health risk was observed from the consumption of these fish for other elements.

\section{Conclusions}

From one-way ANOVA tests, it can be concluded that raw fish samples have generally higher score values than cooked ones and that the score values are mainly higher in September than in March. Therefore, the bioaccessibility of these elements is at its highest mainly in raw fish samples in September. The PCA analyses showed that for both gastric and intestinal phases the

Table 2. Estimated Daily Intakes (EDI) ( $\mathrm{mg} \mathrm{kg}^{-1}$ body weight day ${ }^{-1}$ ) of $\mathrm{Mn}, \mathrm{Fe}, \mathrm{Mn}, \mathrm{Co}, \mathrm{Ni}, \mathrm{Cu}$, As and Se in fish calculated using bioaccessible results of intestinal extractions for $70 \mathrm{~kg}$ of body weight from Marmara Sea assuming $25 \mathrm{~kg}$ of fish consumption per year in the Black Sea region

\begin{tabular}{|c|c|c|c|c|c|c|c|c|c|}
\hline & \multirow[b]{2}{*}{$\mathrm{RDA}^{\mathrm{a}}$} & \multirow[b]{2}{*}{ RFD $^{b}$} & & \multicolumn{6}{|c|}{ Estimated Daily Intakes (EDI) (mg kg-1 body weight day ${ }^{-1}$ ) } \\
\hline & & & & Bream & Anchovy & Horse Mackarel & Sardine & Whiting & Seabass \\
\hline \multirow[t]{4}{*}{ As } & & 0.0003 & September-raw ${ }^{d}$ & 0.00004 & 0.0003 & 0.0001 & 0.0001 & 0.0004 & 0.0003 \\
\hline & & & September-cooked ${ }^{d}$ & 0.0004 & 0.00002 & 0.0001 & 0.0005 & 0.00003 & 0.00004 \\
\hline & & & March-raw & 0.0001 & 0.0001 & 0.0001 & 0.0002 & 0.0001 & 0.0003 \\
\hline & & & March-cooked ${ }^{d}$ & 0.0002 & 0.0003 & 0.00002 & 0.0001 & 0.0002 & 0.00002 \\
\hline \multirow[t]{4}{*}{ Co } & $0.104^{c}$ & 0.01 & September-raw & 0.000003 & $<\mathrm{LOD}^{\mathrm{e}}$ & 0.000003 & $<L O D$ & $<\mathrm{LOD}$ & 0.000001 \\
\hline & & & September-cooked & 0.00001 & 0.00001 & 0.000002 & $<$ LOD & $<$ LOD & $<$ LOD \\
\hline & & & March-raw & 0.000003 & 0.000002 & 0.000001 & $<L O D$ & $<L O D$ & $<L O D$ \\
\hline & & & March-cooked & 0.000004 & 0.000003 & 0.000003 & $<L O D$ & $<L O D$ & $<L O D$ \\
\hline \multirow[t]{4}{*}{$\mathrm{Cu}$} & 0.9 & 0.04 & September-raw & 0.0002 & 0.0001 & 0.0003 & 0.0001 & $<L O D$ & 0.0002 \\
\hline & & & September-cooked & 0.0006 & 0.0002 & 0.0003 & 0.0006 & 0.0001 & 0.0005 \\
\hline & & & March-raw & 0.0003 & 0.0001 & 0.00003 & 0.0001 & 0.0002 & 0.00001 \\
\hline & & & March-cooked & 0.0004 & 0.0002 & 0.00005 & 0.0004 & 0.001 & 0.0002 \\
\hline \multirow[t]{4}{*}{$\mathrm{Fe}$} & 8 for & 0.7 & September-raw & 0.0006 & 0.0002 & 0.001 & 0.003 & & 0.002 \\
\hline & Male & & September-cooked & 0.002 & 0.0006 & 0.002 & 0.002 & 0.002 & 0.002 \\
\hline & 18 for & & March-raw & 0.001 & 0.0007 & 0.0001 & 0.0008 & 0.001 & 0.0001 \\
\hline & Female & & March-cooked & 0.004 & 0.0002 & 0.0005 & 0.005 & 0.003 & 0.002 \\
\hline \multirow[t]{4}{*}{$\mathrm{Mn}$} & 2.3 for & 0.024 & September-raw & 0.000005 & 0.00001 & 0.00002 & $<\mathrm{LOD}$ & $<L O D$ & $<\mathrm{LOD}$ \\
\hline & Male & & September-cooked & 0.0001 & 0 & 0.00004 & 0.00004 & 0.00001 & 0.0001 \\
\hline & 1.8 for & & March-raw & & 0.00001 & 0.00002 & & $<L O D$ & \\
\hline & Female & & March-cooked & 0.0001 & 0.000003 & 0.00003 & 0.00004 & 0.0001 & 0 \\
\hline \multirow[t]{4}{*}{$\mathrm{Ni}$} & & 0.02 & September-raw & 0.00001 & $<L O D$ & 0.00001 & 0.00001 & $<L O D$ & 0.00001 \\
\hline & & & September-cooked & 0.00001 & 0.000005 & $<\mathrm{LOD}$ & 0.00001 & $<L O D$ & 0.00001 \\
\hline & & & March-raw & 0.000003 & & $<L O D$ & & $<L O D$ & $<L O D$ \\
\hline & & & March-cooked & $<L O D$ & 0.00001 & $<L O D$ & 0.00002 & 0.00001 & $<\mathrm{LOD}$ \\
\hline \multirow[t]{4}{*}{$\mathrm{Se}$} & 0.055 & 0.005 & September-raw & 0.0001 & 0.0001 & 0.0001 & 0.00002 & 0.00004 & 0.0001 \\
\hline & & & September-cooked & 0.0001 & 0.0001 & 0.00002 & 0.0002 & 0.00005 & 0.0001 \\
\hline & & & March-raw & 0.0002 & 0.00005 & 0.0001 & 0.0002 & & 0.00003 \\
\hline & & & March-cooked & 0.0001 & 0.00005 & 0.00002 & 0.0001 & 0.0001 & 0.00004 \\
\hline
\end{tabular}

a Recommended dietary allowance (mg/day) (Rayman \& Callaghan. 2006).

${ }^{b}$ Reference oral dose (RfD) (mg/kg bw/day) (JECFA 2003; Department of Environmental Affairs 2016)

'Given as in the form of Vitamin B12 (equivalent to $1.5 \mu \mathrm{g} /$ day Vitamin B12) (Rayman \& Callaghan. 2006).

${ }^{d}$ Concentration of inorganic As was estimated as 10\% of total As (Afonso et al. 2013; Medeirosa, Gobbo dos Santos, Goncalves, Bahia Braga, Krauss

$\&$ do Couto Jacob. 2014).

e $<$ LOD $=$ Under limits of detection. 
Table 3. Hazard Quotient ${ }^{a}$ values for inorganic elements in fish from the Marmara Sea, Turkey

\begin{tabular}{|c|c|c|c|c|c|c|c|c|}
\hline & & $\mathrm{Mn}$ & $\mathrm{Fe}$ & Co & $\mathrm{Ni}$ & $\mathrm{Cu}$ & As & $\mathrm{Se}$ \\
\hline \multirow[t]{4}{*}{ Bream } & September-raw & 0.0002 & 0.001 & 0.0003 & 0.0004 & 0.006 & 0.1 & 0.01 \\
\hline & September-cooked & 0.003 & 0.002 & 0.001 & 0.0005 & 0.01 & 1.3 & 0.03 \\
\hline & March-raw & $<L O D$ & 0.002 & 0.0003 & 0.0001 & 0.006 & 0.2 & 0.05 \\
\hline & March-cooked & 0.005 & 0.006 & 0.0004 & $<$ LOD & 0.01 & 0.6 & 0.03 \\
\hline \multirow[t]{4}{*}{ Anchovy } & September-raw & 0.0004 & 0.0002 & $<L O D$ & $<L O D$ & 0.003 & 0.9 & 0.02 \\
\hline & September-cooked & 0.0001 & 0.001 & 0.001 & 0.0002 & 0.005 & 0.05 & 0.01 \\
\hline & March-raw & 0.001 & 0.001 & 0.0002 & $<L O D$ & 0.002 & 0.2 & 0.01 \\
\hline & March-cooked & 0.0001 & 0.0004 & 0.0003 & 0.001 & 0.006 & 0.9 & 0.01 \\
\hline \multirow[t]{4}{*}{ Horse Mackerel } & September-raw & 0.001 & 0.001 & 0.0003 & 0.001 & 0.007 & 0.2 & 0.02 \\
\hline & September-cooked & 0.002 & 0.002 & 0.0002 & $<L O D$ & 0.006 & 0.3 & 0.005 \\
\hline & March-raw & 0.001 & 0.0001 & 0.0001 & $<$ LOD & 0.001 & 0.4 & 0.02 \\
\hline & March-cooked & 0.001 & 0.001 & 0.0003 & $<L O D$ & 0.001 & 0.06 & 0.004 \\
\hline \multirow[t]{4}{*}{ Sardine } & September-raw & $<L O D$ & 0.004 & $<\mathrm{LOD}$ & 0.0003 & 0.002 & 0.2 & 0.005 \\
\hline & September-cooked & 0.002 & 0.003 & $<L O D$ & 0.001 & 0.02 & 1.7 & 0.04 \\
\hline & March-raw & $<L O D$ & 0.001 & $<$ LOD & $<L O D$ & 0.003 & 0.7 & 0.03 \\
\hline & March-cooked & 0.001 & 0.007 & $<L O D$ & 0.001 & 0.01 & 0.2 & 0.02 \\
\hline \multirow[t]{4}{*}{ Whiting } & September-raw & $<L O D$ & $<L O D$ & $<L O D$ & $<L O D$ & $<\mathrm{LOD}$ & 1.3 & 0.01 \\
\hline & September-cooked & 0.0002 & 0.002 & $<L O D$ & $<L O D$ & 0.003 & 0.10 & 0.01 \\
\hline & March-raw & $<\mathrm{LOD}$ & 0.002 & $<L O D$ & $<L O D$ & 0.006 & 0.2 & \\
\hline & March-cooked & 0.002 & 0.005 & $<\mathrm{LOD}$ & 0.001 & 0.03 & 0.8 & 0.01 \\
\hline \multirow[t]{4}{*}{ Seabass } & September-raw & $<L O D$ & 0.003 & 0.0001 & 0.001 & 0.006 & 0.9 & 0.02 \\
\hline & September-cooked & 0.005 & 0.003 & $<\mathrm{LOD}$ & 0.0003 & 0.01 & 0.1 & 0.01 \\
\hline & March-raw & $<L O D$ & 0.0002 & $<L O D$ & $<L O D$ & 0.0002 & 0.9 & 0.01 \\
\hline & March-cooked & 0.001 & 0.002 & $<L O D$ & $<$ LOD & 0.004 & 0.07 & 0.01 \\
\hline
\end{tabular}

a Hazard Quotient $=\mathrm{EDI} / \mathrm{RfD}$. If the ratio is $<1$, there is no obvious risk.

bioaccessible concentrations of these elements are higher in anchovy than in other fish types. This can be deduced because anchovy has more and higher positive score values for each principal component. Sardines and horse mackerel also have higher positive score values than seabass, bream and whiting. Therefore, the bioaccessibility of these elements is lower in seabass, bream and whiting. Also, the calculated EDI values and the Hazard Quotients values were calculated and showed that there is no health risk to the public from consuming these fish for any of the analytes except for As. This was only for cooked sardines and bream and raw whiting in September. Since the predominant species of As present in fish is the non-toxic arsenobetaine, the conclusion is that there is no hazard to public health originating from As; even if these fish are consumed on a daily basis.

\section{Acknowledgements}

The authors are grateful for the financial support obtained from the Unit of the Scientific Research Projects of Balıkesir University (Project No: 2014/97).

\section{References}

Afonso, C., Costa, S., Cardoso, C., Oliveira, R., Lourenço, H.M., Viula, A., Batista, I., Coelho I., \& Nunes M.L. (2015). Benefits and risks associated with consumption of raw, cooked and canned tuna (Thunnus spp.) based on the bioaccessibility of selenium and methylmercury. Environmental Research, 143, 130-137. https://doi.org/10.1016/j.envres.2015.04.019
Afonso, C., Lourenc, H.M, Cardoso, C., Bandarra, N.M., Carvalho, M.L., Castro, M., \& Nunes, ML. (2013). From fish chemical characterization to the benefit-risk assessment - Part A. Food Chemistry, 137, 99-107. https://doi.org/10.1016/j.foodchem.2012.10.003

Burger, J., Dixon, C., Boring, S., \& Gochfeld M. (2003). Effect of deep-frying fish on risk from mercury. Journal of Toxicology and Environmental Health, Part A, 66, 817828. https://doi.org/10.1080/15287390306382

Cave, M.R.,Wragg, J., Palumbo, B., \& Klinck, B.A. (2002). Measurement of the bioaccessibility of arsenic in UK soils. Technical report. R\&D Technical Report P5062/TR02. British Geological Survey, Environmental Agency.

Crews, H.M., Burrell,JA., \& McWeeny, D.J. (1983). Preliminary enzymolysis studies on trace element extractability from food. Journal of the Science of Food and Agriculture, 34, 997-1004. https://doi.org/10.1002/jsfa.2740340917

Department of Environmental Affairs. (2010). The Framework for the Management of Contaminated Land., South Africa. Retrieved from http://sawic.environment.gov.za/documents/562.pdf

Ekovitrin.com. (2015). Hangi ayda hangi balık türü iyi gider? Retrieved from http://www.ekovitrin.com/guncel/hangi-ayda-hangibalik-turu-iyi-gider-h58528.html

Ersoy, B.,Yanar, Y.,Küçükgülmez, A.,\& Çelik M. (2006). Effects of four cooking methods on the heavy metal concentrations of sea bass fillets (DicentrarchuslabraxLinne., 1785). Food Chemistry, 99, 748-751.

https://doi.org/10.1016/j.foodchem.2005.08.055

Ersoy, B., \& Zeren Ö. (2009). The effect of cooking methods on mineral and vitamin contents of African catfish. Food Chemistry, 115, 419-422. https://doi.org/10.1016/j.foodchem.2008.12.018 
EUMOFA. (2018). The EU fish market. http://agricultura.gencat.cat/web/.content/de_departa ment/de02_estadistiques_observatoris/27_butlletins/0 2_butlletins_nd/documents_nd/fitxers_estatics_nd $/ 20$ 18/0218_2018_Pesca_Productes-pesquers-mercats-UE2018-exportacions.pdf (accessed at 26.06.2019).

FAO. (2018). The state of fisheries and aquaculture. Meeting the sustainable development goals. http://www.fao.org/3/19540EN/i9540en.pdf (accessed at 26.06.2019).

Gao, S., \& Wang, W.X. (2014). Oral bioaccessibility of toxic metals in contaminated oysters and relationships with metal internal sequestration. Ecotoxicology and Environmental Safety, 110, 261-268. https://doi.org/10.1016/j.ecoenv.2014.09.013

Garrett, D.A., Failla, M.L., \& Sarama R.J. (1999). Development of an in vitro digestion method to assess carotenoid bioavailability from meals. Journal of Agricultural and Food Chemistry, 47, 4301-4309. https://doi.org/10.1021/jf9903298

Gokoglu, N.,Yerlikaya, P., \& Cengiz, E. (2004). Effects of cooking methods on the proximate composition and mineral contents of rainbow trout (Oncorhynchus mykiss). Food Chemistry, 84, 19-22. https://doi.org/10.1016/S03088146(03)00161-4

Guillen, J., Natale, F., Carvalho, N., Casey, J., Hofherr, J., Druon, J.N., Fiore, G., Gibin, M., Zanzi, A., \& Martinsohn, J. T. (2019). Global seafood consumption footprint. Ambio, 48, 111-122. https://doi.org/10.1007/s13280-0181060-9

Güngör, A., \& Kara, D. (2018). Toxicities and risk assessment of heavy metals of the six most consumed fish from the Marmara Sea. Environmental Science and Pollution Research, 25, 2672-2682. https://doi.org/10.1007/s11356-017-0672-0

Hack, A., \& Selenka F. (1996). Mobilization of PAH and PCB from contaminated soil using a digestive tract model. Toxicology Letters, 88, 199-210. https://doi.org/10.1016/0378-4274(96)03738-1

He, M., Ke, C., \& Wang, W. (2010). Effects of Cooking and Subcellular Distribution on the Bioaccessibility of Trace Elements in Two Marine Fish Species. Journal of Agricultural and Food Chemistry, 58, 3517-3523. https://doi.org/10.1021/jf100227n

Intawongse, M., \& Dean, J.R. (2006). Uptake of heavy metals by vegetable plants grown on contaminated soil and their bioavailability in the human gastrointestinal tract. Food Additives and Contaminants, 23, 36-48. https://doi.org/10.1080/02652030500387554

Intawongse, M., \& Dean, J.R. (2008). Use of the physiologicallybased extraction test to assess the oral bioaccessibility of metals in vegetable plants grown in contaminated soil. Environmental Pollution, 152, 60-72. https://doi.org/10.1016/j.envpol.2007.05.022

JECFA. (2003). Joint Food and Agriculture Organization/World Health Organization Expert Committee on Food Additives. Summary and Conclusions of the 61st Meeting of the Joint FAO/WHO Expert Committee on Food Additives., JECFA/61/Sc., Rome., Italy., 1-22 pp.

Kafaoglu, B., Fisher, A., Hill, S., \& Kara, D. (2016). Determination and evaluation of element bioaccessibility in some nuts and seeds by in-vitro gastro-intestinal method. Journal of Food Composition and Analysis, 45, 58-65. https://doi.org/10.1016/j.jfca.2015.09.011
Lorenzi, D., Entwistle, J., Cave, M., Wragg, J.,\& Dean JR. (2012). The application of an in vitro gastrointestinal extraction to assess the oral bioaccessibility of polycyclic aromatic hydrocarbons in soils from a former industrial site. Analytica Chimica Acta, 735, 54-61. https://doi.org/10.1016/j.aca.2012.05.030

Medeirosa, R.J., Gobbo dos Santos, L.M., Goncalves, J.M., Bahia Braga, A.M.C., Krauss, T.M., \& do Couto Jacob, S. (2014). Comparison of the nutritional and toxicological reference values of trace elements in edible marine fish species consumed by the population in Rio De Janeiro State., Brazil. Toxicology Reports, 1, 353-359. https://doi.org/10.1016/j.toxrep.2014.06.005

Meunier, L.,Wragg, J., Koch, I., \& Reimer, K.J. (2010). Method variables affecting the bioaccessibility of arsenic in soil. Journal of Environmental Science and Health, Part A, 45, 517-526. https://doi.org/10.1080/10934521003594863

Miller, D., Schricker, B., Rasmussen, R., \& Van Campen, D. (1981). An in vitro method for estimation of iron availability from meals. The American Journal of Clinical Nutrition, 34, 2248-2256. https://doi.org/10.1093/ajcn/34.10.2248

Oomen, A.G., Rompelberg, C.J.M., Bruil, M.A., Dobbe, C.J.G., Pereboom, D.P.K.H., \& Sips A.J.A.M. (2003). Development of an in vitro digestion model for estimating the bioaccessibility of soil contaminants. Archives of Environmental Contamination and Toxicology, 44, 281-287. https://doi.org/10.1007/s00244-002-1278-0

Palumbo-Roe, B., Cave, M.R., Klinck, B.A., Wragg, J., Taylor, H., O'Donnell, K., \& Shaw, R.A. (2005). Bioaccessibility of arsenic in soils developed over Jurassic ironstones in eastern England. Environmental Geochemistry and Health, 27, 121-130. https://doi.org/10.1007/s10653005-0128-1

Perello, G., Martí-Cid, R., Llobet, J.M., \& Domingo, J.L. (2008). Effects of various cooking processes on the concentrations of arsenic, cadmium, mercury and lead in foods. The Journal of Agricultural and Food Chemistry, 56, 11262-11269. https://doi.org/10.1021/jf802411q

Ouedraogo, O., \& Amyot, M. (2011). Effects of various cooking methods and food components on bioaccessibility of mercury from fish. Environmental Research, 111, 10641069. https://doi.org/10.1016/j.envres.2011.09.018

Rayman, M., \& Callaghan, A. (2006). Appendix 3: Table of UK and USA Dietary Reference Values for Vitamins., Minerals and Trace Elements., in Nutrition and Arthritis., Blackwell Publishing Ltd., Oxford., UK. Retrieved from: https://doi.org/10.1002/9780470775011.app3

Ruby, M.V., Davis, A., Link, T.E., Schoof, R., Chaney, R.L., Freeman, G.B., \& Bergstrom, P. (1993). Development of an in vitro screening test to evaluate the in vivo bioaccessibility of ingested mine-waste lead. Environmental Science \& Technology, 27, 2870-2877. 10.1021/es00049a030

Simopoulos, A.P. (1997). Nutritional Aspects of Fish. In Seafood from Producer to Consumer, Integrated Approach to Quality. (Luten JB.,Børresen T.,Oehlenschläger J Eds) Elsevier Science Publishers., Amsterdam. 589-607 pp.

Sioen, I.,Henauw, S.D.,Verdonck, F.,Thuyne, N.V., \& Camp J.V. (2007). Development of a nutrient database and distributions for use in a probabilistic risk-benefit analysis of human seafood consumption. Journal of Food 
Composition and Analysis, 20 (8), 662-670. https://doi.org/10.1016/j.jfca.2006.11.001

Van het Hof, K.H., West, C.E., Weststrate, J.A., \& Hautvast, J.G.A.J. (2000). Dietary factors that affect the bioavailability of carotenoids. The Journal of Nutrition, 130, 503-506. https://doi.org/10.1093/jn/130.3.503

Versantvoort, C., Oomen, A,G., Van de Kamp, E., Rompelberg, C., \& Sips, A. (2005). Applicability of an in vitro digestion model in assessing the bioaccessibility of mycotoxins from food. Food and Chemical Toxicology, 43, 31-40. https://doi.org/10.1016/j.fct.2004.08.007

Wang, H.S., Xu, W.F., Chen, Z.J., Cheng, Z., Ge, L.C., Man, Y.B., Giesy, J.P., Du, J., Wong, C.K.C.,\& Wong, M.H. (2013). In vitro estimation of exposure of Hong Kong residents to mercury and methylmercury via consumption of market fishes. Journal of Hazardous Materials, 248, 387-393. https://doi.org/10.1016/j.jhazmat.2012.12.060

Wienk, K.J.H., Marx, J.J.M., \& Beynen, A.C. (1999). The concept of iron bioavailability and its assessment. European Journal of Nutrition, 38, 51-75. https://doi.org/10.1007/s003940050046

Wragg, J., Cave, M., \& Nathanail, P. (2007). A study of the relationship between arsenic bioaccessibility and its solid-phase distribution in soils from Wellingborough., UK. Journal of Environmental Science and Health. Part A, Toxic/hazardous Substances \& Environmental Engineering, 42, 1303-1315. https://doi.org/10.1080/10934520701436062 